\title{
LOS ORÍGENES DEL MOVIMIENTO FEMINISTA: LA CRUZADA DE HARRIET BEECHER STOWE
}

\author{
M." Paz Kindelán \\ Universidad Complutense
}

La posición de la mujer en la sociedad americana del siglo XIX estaba en función del papel primordial que desempeñaba en su hogar como esposa y madre. Su actividad se restringía esencialmente al cuidado material del hogar, junto con las obligaciones domésticas hacia su marido e hijos. Sin embargo, su autoridad iba más allá de lo puramente doméstico, pues bajo su responsabilidad también quedaba asegurado el tono o carácter espiritual y moral de la familia. De ahi que la expresión «el ángel de la casa»-empleada por el escritor Coventry Patmore en su obra The Angel of the House - englobaba no sólo el poder que ejercía como "guardián» de los valores cristianos en el círculo familiar, sino también su superioridad moral sobre el hombre. Si él era el cabeza de familia y su dominio se extendía principalmente al mundo profesional, político y económico, ella había de procurar el bienestar de los suyos en el terreno privado de la casa. La división entre ambas esferas - la del marido de un lado y la de la mujer de otro- aseguraba además el mutuo respeto entre ambos cónyuges, pues aunque la mujer en todo momento debe someterse al marido, la autonomía e influencia que aquélla ejercía en la familia redundaba en la estabilidad y el orden de toda la sociedad.

El ideal victoriano denominado «el culto a la verdadera feminidad» proclamaba a la mujer como agente de la moralidad designado por el mismo Dios, con la consiguiente responsabilidad de ejecutar tal poder en la familia, a fin de refinar los afectos humanos del «hombre» y elevar sus sentimientos morales'. El hogar simbolizaba todo un cúmulo de valores femeninos de la

' Sara Josepha Hale's quotation in Phillida Bunkle: «Sentimental Woman hood and Domestic Education, 1830-1870», in History of Education Quartely, 14. Spring, 1974, p. 23. 
piedad, el sacrificio y el afecto, mientras que la familia aparecía como el ejemplo más ilustrativo del reino celestial; de ahí que la mujer se erigiese en ministro principal, desempeñando las mismas tareas sagradas que un recién ordenado.

La dependencia de la mujer con respecto al marido no solamente exigía de ella una absoluta sumisión, sino que, sobre todo, proporcionaba a aquél el apoyo emocional y la fortaleza moral que necesitaba en todo momento. De este modo, la competitividad, autoafirmación e individualismo imperante en el mundo masculino, se compensaba con la benevolencia, desinterés, pureza y mansedumbre femenina. Aquí es donde verdaderamente quedaba demostrada la superioridad de la mujer, si bien la relación establecida en el matrimonio americano se caracterizaba fundamentalmente por el compañerismo reinante entre ambas partes.

Cabe destacar aquí la obra de las hermanas Catherine E. Beecher y Harriet Beecher Stowe titulada The American Woman's Home (1869), en la que ambas escritoras enumeran las características esenciales de una familia cristiana, al tiempo que subrayan las numerosas obligaciones del ama de casa. Frente a toda visión negativa de las labores domésticas, destacarán la idea de que la vida familiar - junto con el trabajo que ésta lleva consigono es algo menospreciable o degradante para la mujer, sino, más bien, todo lo contrario: le confiere una dignidad y categoria comparables a la del hombre, necesitando así del oportuno entrenamiento y aprendizaje para desempeñarla:

\footnotetext{
The authors of this volume, while they sympathize with every honest effort to relieve the disabilities and sufferings of their sex, are confident that the chief cause of these evils is the fact that the honor and duties of the family state are not duly appreciated, that women are not trained for these duties as men are trained for their trades and professions, and that, as a consequence family labor is poorly done, poorly paid, and regarded as menial and disgraceful ${ }^{2}$.
}

En verdad, ambas autoras veian el hogar como parte integral del sistema nacional, en cuanto que reflejaba y promocionaba la cultura y los valores americanos esenciales. Asimismo, eran partidarias de la opinión de que la mujer pertenecía primordialmente a su hogar, núcleo central de la comunidad, y por tanto había que formarla cristianamente en su papel de madre y esposa en virtud de la posición que ocupaba en la sociedad como guía

Beecher, Catherine E., \& Beecher Stowe, Harriet: «Introduction» to The American Woman's Home, or Principles of Domestic Science. New York, J. B. Ford and Company, 1969, p. 13. 
moral de toda la nación. Disciplina, renuncia y amor sacrificado eran las cualidades que debían acompañar al estado matrimonial. De acuerdo con estas características, la mujer desempeñaba el oficio de criar a los hijos y cuidar de su hogar, mientras el marido ganaba el sustento para mantener a los suyos en el mundo profesional. No obstante, uno y otro debían velar por los hijos desde la infancia, a fin de que adquiriesen los buenos hábitos de la honradez, la obediencia y la benevolencia. Estas y otras recomendaciones dispersas en los capítulos de "Health of Mind», "Care of Infants", «Early Rising», etc., giraban en torno al ideal de un hogar cristiano, al que debian aspirar todas las familias.

Pero si el papel de la mujer era tan absolutamente central, de ahí se deducía lógicamente la absoluta necesidad de proporcionarle una educación adecuada para asumir tan alta responsabilidad. A propósito de ello, Catherine Beecher habia escrito en su Treatise on Domestic Economy, publicado en 1834: "The proper education of a man decides the welfare of an individual; but educate a woman and the interests of a whole family are secured $\iota^{3}$. Así y todo, la educación de la mujer en la Nueva Inglaterra del siglo XVII era muy rudimentaria, y generalmente se reducia a unas cuantas habilidades u "ornamentals», consideradas como indispensables para lograr el fin deseado: el matrimonio. En la década de 1820, sin embargo, comenzarian a erigirse nuevas academias y seminarios orientados a mejorar la preparación de las alumnas para su futura posición de esposas y madres de familia.

A este nuevo avance vino a oponerse el doble argumento de que una educación superior para la mujer la haría poco atractiva para el hombre, aparte de que la mente femenina no estaba capacitada para adquirir los mismos conocimientos. Es más, la idea de una educación idéntica para ambos sexos se veía como un grave atentado contra el rol que tradicionalmente se adjudicaba a la mujer en la sociedad del siglo XIX. No obstante, tras una prolongada controversia sobre su posible acceso a centros de enseñanza superior, tanto los «colleges» como las universidades más prestigiosas (Oberlim y Harvard, respectivamente) terminaron por abrir sus puertas a un número reducido de alumnas. Precisamente esta élite de mujeres americanas «educadas» luchará por un pleno reconocimiento de su estatus y la participación en todas las profesiones sin discriminación. El resultado de esta experiencia no tardaría en hacerse patente, en la progresiva modificación del papel tradicional de la mujer en la sociedad americana de finales del siglo XIX y principios del XX. Por lo pronto, tendrá lugar un desgajamiento de su personalidad. El hecho de tener un empleo, además de las labores domésticas, hará que su situación sea más independiente dentro del

${ }^{3}$ Beecher, Catherine E.: A Treatise on Domestic Economy for the use of Young Ladies at Home and at School. Boston, Thomas H. Webb \& Co., 1842, p. 37. 
matrimonio, en cuyo estado siempre perdía todos sus bienes y privilegios en favor del marido. Aunque también es verdad que las pésimas condiciones del trabajo (hacinamiento, exceso de horas, escasa ventilación, etc.), sumadas al tipo de ocupación que ejercía de acuerdo con sus escasas habilidades (docencia, enfermería, industria textil, etc.) y el pequeño salario que cobraba ${ }^{4}$, todo ello contribuiría a forjar una nueva imagen de la mujer americana en desafio a las convenciones de su propia esfera. Concretamente el campo de la literatura - al que se habian lanzado un buen número de escritoras en su mayoria desconocidas-, era una de las profesiones más atacadas por la opinión pública, dado el carácter poco femenino de dicho oficio.

En efecto, el proceso de industrialización que barrió toda la nación durante la década de 1830 , no excluyó la mano de obra femenina. Las nuevas fábricas textiles y tabacaleras absorberían gran parte de la población nativa, siendo pronto sustituida por inmigrantes o bien otras razas, fundamentalmente negra. Esta mano de obra, a diferencia de los empleos anteriormente mencionados, constituia una fuente de recursos y beneficios para la nueva sociedad que estaba emergiendo. Si bien es verdad que la Revolución Industrial no causó directamente el nacimiento del movimiento feminista en América, sí que proporcionó el contexto adecuado para lanzar un primer ataque a las ideas prevalecientes sobre la posición y el papel de la mujer en la sociedad de aquel entonces. La gran expansión hacia la frontera, los nuevos medios de transporte, el desarrollo de nuevas instituciones económicas, y la expansión de la democracia provocó una gigantesca conmoción social. En medio de este proceso, la colaboración de la mujer en actividades religiosas o humanitarias iba a demostrar de modo patente su influencia espiritual no sólo en el círculo familiar sino también a nivel de toda la nación. Así se explica el compromiso de las primeras «activistas» en pro de la abolición de la esclavitud, lo cual traería consigo un planteamiento de la emancipación y los derechos debidos a su propio sexo. En efecto, las hermanas Grimké, ardientes abolicionistas, procedentes de una familia de $\mathrm{Ca}$ rolina del Sur propietaria de esclavos, no tardarian en proclamar dicha discriminación.

4 "The myths that women worked for "pin money"; that they worked only temporarily until marriage; that they had no interest and motivation to upgrade their skills, reinforced existing prejudices against workers and perpetuated their low status").

Lerner, Gerda: The Female Experience. Indianapolis, The Bobbs-Merrill Company Inc., 1977 , p. 258. 
... What can woman do for slaves when she herself is under the feet of man and shamed into silence?

La culminación de este movimiento tendrá lugar en una convención celebrada en "Seneca Falls" (New York) los días 19 y 20 de julio de 1848, en la que se reunieron alrededor de 300 hombres y mujeres para expresar un alegato radical —calificado como una «Declaración de Sentimientos»- en contra de la exclusión de la mujer de todas las esferas sociales y profesionales gobernadas por el hombre. En realidad, venía a ser una revisión de la «Declaración de la Independencia» de 1776, con el objetivo primordial de obtener la igualdad de ambos sexos en la sociedad americana en nombre de los derechos humanos. El documento resultante se convertiría en la piedra de toque del movimiento feminista, cuyas demandas se dejarían oír tanto en el Congreso como en las asambleas públicas: «Lo mismo que a los negros - argüirán las hermanas Grimké-, se acusa a la mujer de inferioridad mental, se la priva de los derechos básicos de todo ciudadano libre, y se la excluye del terreno político, educativo y económico." Si a los primeros ni siquiera se les reconocía como personas jurídicas, a las segundas se las destituía del control legal sobre la propiedad y de toda clase de posesiones, las cuales una vez celebrado el matrimonio pasaban inmediatamente al dominio del marido. Pero la discriminación alcanzaba su cota más alta en lo que concernía al estatus social: ambos grupos mantenían una posición inferior de sumisión y dependencia con respecto al hombre: o dicho de otro modo, ni la mujer ni el negro podían jamás aspirar al sueño americano de movilidad en la escala social, y menos aún lograr su propia realización como personas, porque les estaba asignado un puesto servil e ineficaz, que comportaba una serie de obligaciones y deberes ineludibles. En una palabra, las etiquetas de la raza y el sexo determinaban tanto su identidad como su función en la sociedad.

La convención de «Seneca Falls» en 1848 como primer exponente de la declaración de derechos de la mujer y su aspiración al sufragio, hubo de parecer, sin duda alguna, una acción radical y subversiva, imposible de acomodar a la doctrina de las «dos esferas». De hecho, el objetivo del sufragio era destruir las barreras que separaban ambos dominios, exaltando con ello la esencia misma del feminismo; se trataba de consolidar la individualidad e independencia de la mujer, asumiendo su propio interés y su existencia como persona distinta del hombre.

' Lerner, Gerda: The Grimké Sisters from South Carolina. Rebels against Slavery. Boston. Houghton Miffin Company, 1967, pp. 192 y 201. 
Whatsoever it is morally right for a man to do, it is morally right for a woman to do.

I recognize no rights but human rights. I know nothing of men's rights and women's rights; for in Christ Jesus there is neither male nor female. Sure I am that woman is not to be, as she has been, a mere second hand agent in the regeneration of a fallen world, but the acknowledged co-equal and co-worker with man in this glorious work ${ }^{6}$.

Dicha igualdad entre ambos sexos ya habia sido defendida por la escritora Mary Wollestonecraft en Vindication of the Rights of Woman (1792), y ratificada posteriormente por el ilustre filósofo inglés John Stuart Mill en su obra The Subjection of Women (1869), en donde exponía claramente la idea de que la subordinación femenina era consecuencia del resultado de la opresión política por parte del hombre?

Sin embargo, no existe ningún otro libro en la historia de los Estados Unidos que haya influenciado tan poderosamente el destino del pueblo americano en su período más crítico, como Uncle Tom's Cabin (1852). No es que su autora, Harriet Beecher Stowe, se propusiera contribuir con esta obra a la vertiente principal de la literatura americana, sino que simplemente escogería una realidad política - la esclavitud- que a su parecer estaba devastando la nación, al desintegrar los lazos familiares y destruir así el pilar fundamental sobre el que se asentaba el bienestar y la seguridad de toda una sociedad: el principio de igualdad y libertad, defendido por los primeros colonizadores desde su asentamiento en la Nueva Inglaterra. En efecto, la esclavitud para Stowe equivalia a un pecado nacional; por eso, "Uncle Tom's Cabin is a work of providential history which seeks to do-

- Grimke, Sarah M.: Letters on the Equality of the Sexes and the Condition of Woman. Addressed to Mary S. Parker, President of the Boston Female Anti-Slavery Society. Boston, Isaac Knapp, 1838, pp. 122 y 116-117.

" "Gracious Creator of the whole human race!", exclama Mary Wollstonecraft, "has thou created such a being as woman, who can trace thy wisdom in thy works, and feel that thou alone art by thy nature, exalted above her - for no better purpose? Can she believe that she was only made to submit to man her equal; a being, who, like her, was sent into the world to acquire virtue? Can she consent to be occupied merely to please him; merely to adorn the earth, when her soul is capable of rising to thee? And can she rest supinely dependent on man for reason; when she ought to mount with him the ardous steps of knowledge?»

Hardt, Ulrich H.: A Critical Edition of Mary Wollstonecraft's 'A Vindication of the Rights of Woman: With Strictures on Political and Moral subjects'. New York (Troy), The Whitston Publishing Company, 1892, p. 151.

Y John Stuart Mill, a propósito del monopolio ejercido por el «otro sexo" añadiría refiriéndose a las mujeres: «I believe that their disabilities elsewhere are only clung to in order to maintain their subordination in domestic life; because the generality of the male sex cannot yet tolerate the idea of living with en equal.»

Stuart Mill, John: The Subjection of Women. Massachusetts (Cambridge) The MIT Press, 1970 , p. 3. 
cument the contemporary scene in order to move its readers to return the nation to its true historical course by purging it of the $\sin$ of slavery ${ }^{8}$. $Y$ la forma de purgarlo, y volver de nuevo a las raices históricas de la nación, es reconocer la maldad de dicha institución. No ya de las personas singulares -explica Stowe-, puesto que los culpables no son sólo los propietarios o los capataces, sino todos aquellos que aceptan y explotan el comercio de esclavos como una fuente de recursos económicos. Y esos, dice Agustine St. Clare, somos tanto el Sur como el Norte:

«I declare to you», said he, suddenly stopping before his cousin «(its's no sort of use to talk or to feel on this subject), but I declare to you, there have been times when $I$ have thought, if the whole country would sink, and hide all this injustice and misery from the light, I would willingly sink with it. When I have been travelling up and down on our boats, or about on my collecting tours, and reflected that every brutal, disgusting, mean, low-lived fellow 1 met, was allowed by our laws to become absolute despot of as many men, women and children, as he could cheat, steal, or gamble in actual ownership of helpless children, of young girls and women, - I have been ready to curse my country, to curse the human race! $)^{9}$.

Harriet Beecher Stowe había visto de cerca los horrores de la esclavitud de la raza negra durante los años que vivió en Cincinnati (1832-1850), e incluso había visitado a algunos de los propietarios en Kentucky, uno de los principales focos del tráfico de esclavos. Pero la aprobación de "The Fugitive Slave Law' en 1850 , por la que se exigía a todo ciudadano de los Estados libres la devolución de los esclavos a sus respectivos dueños, fue sin duda la gota que hizo rebosar su indignación frente a quienes parecían dispuestos a "nacionalizar» tal barbarie.

Stowe ya había publicado una historia corta en 1845 con el título de Immediate Emancipation, apelando a los Estados del Sur para que liberasen

"Alice C. Crozier, The Novels of Harriet Beecher Stowe. New York, Oxford University Press, 1969, p. 35.

'Harriet B., Stowe, Uncle Tom's Cabin or Life among the Lowly. Harmondsworth: Penguin Books Ltd., Ist published, in the Penguin American Library 1981, rpt. 1987, p. 332.

En $1889, \mathrm{~J}$. H. Beadle diria a este respecto: "It was her aim to show that the evils of slavery were the evils of a bad system, and not always the fault of those who had become involved in it were its actual administrators.

With clear logic the writer showed that the North and South were equally responsible for the continuance of a system which opposed to the first grand principle of Christianity, "Thou shalt love thy neighbor as thyself"."

Harriet Beecher Stowe Collection, Folder n. 380 a: Literature: $A$ Weekly Magazine, (Febr. 16,1889 ), by H. H. Beadle, pp. 289, 389. 
a los esclavos. Y poco después en 1850 saldría a la luz otro relato aún más comprometedor, The Freeman's Dream: $A$ Parable, por aludir directamente a la doctrina de la retribución divina como último recurso; pero tampoco fue lo suficientemente eficaz. Por fin, a finales de ese mismo año, su cuñada Mrs. Edward Beecher urgió a Harriet para que utilizase su talento artístico y escribiese algo contra los abusos que se estaban cometiendo contra los negros: «If I could use a pen as you can... I would write something that would make this whole nation feel what an accursed thing slavery is»; nada más terminar de leer la carta a su familia, nuestra autora expresó su asentimiento con gran determinación: "I will write something... I will if I live» ${ }^{10}$. De hecho, en enero de 1851 ya habia mantenido una conversación con su hermano Henry Ward (pastor de una prestigiosa iglesia en Brooklyn), en la que ambos intercambiaron sus planes y opiniones con respecto al deseo común de combatir la "dictadura tiránica» de los propietarios del Sur: «I have begun a story, trying to set forth sufferings and wrongs of the slaves», le dijo ella; y Henry le contestó: «That's right, Hattie»... «finish it and I will scatter it thick as the leaves of Vallambrosa, and so came Uncle Tom... ${ }^{11}$. En medio de sus innumerables labores domésticas como madre de siete niños (uno de los cuales falleció), dicha empresa se presentaba ardua; pero la estrechez económica por la que estaba atravesando su familia en esos momentos acabó por convencerla. A continuación, probablemente en febrero de 1851, durante la comunión en uno de los servicios religiosos de la parroquia a la que acudía habitualmente en Brunswick - ciudad a la que se trasladó en 1850 desde Cincinnati- de repente vino a su mente de una forma clara (lo que ella más tarde describiría como una "visión») la escena de la muerte de Uncle Tom, el protagonista de su historia. Al llegar a casa, inmediatamente la puso por escrito en un papel burdo que envolvía un paquete, y se la leyó a sus dos hijos Henry y Frederick, de 12 y 10 años de edad, los cuales comenzaron a llorar al oír la terrible descripción de los latigazos que terminan con la vida de Uncle Tom, y uno de ellos exclamó: "Oh, mamma! slavery is the most cruel thing in the world" ${ }^{12}$.

Partiendo de esta convicción - la crueldad e injusticia de la esclavitud-, Stowe se lanzará a presentar al mundo un cuadro realista, teñido de horror y de compasión por la raza negra tan vilmente explotada. Lo que en un principio iba a ser una serie de bocetos editados en el periódico semanal

${ }^{10}$ Citado por Charles E. Stowe, The Life of Harriet Beecher Stowe, compiled with her letters and journals. Boston \& New York, Houghton, Mifflin and Company, 1889, p. 145.

" «Harriet Beecher Stowe to George Eliot» (March 18, 1876), Berg Collection, New York Public Library, quoted in E. Bruce Kirkham: Harriet Beecher Stowe and the Genesis, Composition, and Revision of Uncle Tom's Cabin. University of North Carolina, Ph. D. diss., 1968, p. 118.

12 Forrest Wilson, The Life of Harriet Beecher Stowe, New York, J. B. Lippincott Company, 1941, pp. 26-7. 
"The National Era» en $1851^{13}$, se convirtió finalmente en un libro de un éxito inmediato y rotundo. En un año se vendieron alrededor de unos 300.000 ejemplares. Pero los efectos del libro en el Sur provocaron un revuelo de indignación: tanto la escritora como la obra fueron denunciados desde el púlpito y por la prensa como terminantemente 'anticristiana'. Stowe se sorprendió de los duros ataques, cuando precisamente había esperado que su obra sirviera de "gran pacificadora", uniendo Norte y Sur en una misma cruzada.

Aun así, Uncle Tom's Cabin triunfaría rápidamente en Inglaterra y en otros países, traduciéndose a diversas lenguas y siendo representada en los Estados Unidos en 1852. Sin embargo, la escritora no recibió ningún beneficio económico, salvo los derechos de autor en su propia tierra, lo que le permitió salir de la indigencia y continuar al mismo tiempo su carrera literaria.

El gran impacto de Uncle Tom's Cabin resultó indudablemente del retrato fiel del negro como ser humano, atrapado en un sistema despiadado y feroz, capaz de violar los sentimientos humanos más intimos. La universalidad de esta apelación a la justicia hecha por Stowe en nombre de la humanidad hace que la obra trascienda los limites de la diferenciación racial a fin de demostrar la igualdad básica y fundamentalmente cristiana de todos los hombres. La escritora, no obstante, trataría el tema de la esclavitud en función de los efectos producidos en el sistema doméstico, no como quien se pone a narrar una historia, sino más bien como el que "pinta» de un modo gráfico y fiel ${ }^{14}$ los sufrimientos y reveses que atraviesan los personajes negros, cuando se ven forzados a romper los lazos familiares y someterse a los abusos de sus dueños. Convencida del poder que ostentan las mujeres

${ }^{3}$ En marzo de 1851, Harriet escribió la carta más importante de su vida a Gamaliel Bailey, editor de "The National Era»: I am at present occupied upon a story which will be a much longer one than any I have ever written, embracing a series of sketches which give the lights and shadows of the "patriarchal institution", written either from observation, incidents which have occurred in the sphere of my personal knowledge, or in the knowledge of my friends. I shall show the best side of the thing, and something faintly approaching the worst.

Up to this year I have always felt that I had no particular call to meddle with this subject... But I feel now that the time is come when even a woman or a child who can speak a word for freedom and humanity is bound to speak... My vocation is simply that of a painter, and my object will be to hold up in the most lifelike and graphic manner possible Slavery, its reverses, changes, and the negro character, which I have had ample opportunities for studying. There is no arguing with pictures, and everybody is impressed by them, whether they mean to be or not. The thing may extend through three or four numbers. It will be ready in two to three weeks.

Citado por E. Bruce Kirkham: The Building of Uncle Tom's Cabin. Knoxville, The University of Tennessee Press, 1977, pp. 66-7.

${ }_{14}$ "My vocation is simply that of a painter, and my object will be to hold up in the most lifelike and graphic manner possible Slavery, its reverses, changes, and the negro character...» Ibidem, p. 67. 
cristianas de su época para salvar la nación de cualquier tipo de opresión, Stowe dramatiza las ideas de su hermana Catherine en lo que se ha denominado "feminismo doméstico", que constituye de hecho el principio regulador de su obra Uncle Tom's Cabin. Incluso va más allá de la pura idealización victoriana de la mujer como madre y esposa, al insistir en la importancia y el carácter sagrado de los valores maternales no sólo en el ámbito del hogar, sino también en toda la sociedad, en tanto en cuanto se apliquen a cada una de las esferas que componen la vida americana. La fuerza moral de dicha "maternidad», en la que se asumen las virtudes esencialmente femeninas de la piedad, la pureza, la sumisión, etc. puede transformar toda una nación, hasta tal punto que la ruptura o desintegración de ese vínculo maternal supone un riesgo incalculable para la seguridad y bienestar social. A propósito de ello, Elizabeth Ammons en su estudio «Stowe Dream of the Mother-Savior» afirma que «la maternidad era ya un concepto sumamente politizado cuando Harriet Beecher Stowe escribió Uncle Tom's Cabin ${ }^{15}$. Y la razón de esta politización está en que dicho concepto se pone al servicio del hombre: es decir, desde el comienzo de la obra, lo que vemos es la destrucción de una familia - unidad básica de la comunidad- por parte del hombre blanco. Mr. Shelby vende a Tom, el negro que le meció en sus brazos cuando él todavía era un bebé, y al pequeño Harry -el hijo de Eliza - a pesar de las protestas de Mrs. Shelby, que como buena madre cristiana ve en la esclavitud una maldición:

"This is God's curse on slavery! - a bitter, bitter, most accursed thing!- a curse to the master and a curse to the slave! I was a fool to think I could make anything good out of such a deadly evil.

"Abolitionists! if they know all I know about slavery, they might talk! We don't need them to tell us; you know I never thought that slavery was right -never felt willing to own slaves $)^{16}$.

Stowe, de hecho, define dicha institución como una «abominación contra Cristo y contra la maternidad». Éstas son sus palabras dos años después de la publicación de Uncle Tom's Cabin: "This story is to show how Jesus Christ, who liveth and was dead, and now is alive and forevermore, has still a mother's love for the poor and lowlys" ${ }^{17}$. Esta experiencia maternal y la elevación de los valores femeninos a un plano sobrenatural explica la pe-

1s Elizabeth Ammons, "Stowe's Dream of the Mother-Savior", in New Essays on Uncle Tom's Cabin, ed. by Eric K. Sundquist, Cambridge University Press, Cambridge, 1986, p. 160.

${ }^{16}$ Harriet B. Stowe, Uncle Tom's Cabin, op. cit., pp. 84-5.

${ }^{17}$ Charles E. Stowe, The Life of Harriet Beecher Stowe, op. cit., 1890, pp. 154. 
culiar caracterización de los dos personajes centrales de su obra: Uncle Tom y Eva. En efecto, Stowe va a sustituir la autoridad masculina imperante en la sociedad por un tipo de amor encarnado en la figura cristiforme de Evangeline o Eva - cuyo nombre nos trae a la memoria a la madre de la raza humana- e igualmente en la naturaleza sumisa, leal, paciente y sacrificada -característica de las heroinas del siglo XIX- de Uncle Tom ${ }^{18}$. El hecho es que ambos actuarán como el principio redentor del mundo corrompido por la violencia de la esclavitud, entonces conocida como «the patriarchal institution». La figura de Eva irradia dulzura e inocencia, un amor maternal y casi divino que regenera los impulsos egoístas e inhumanos de cuantos la rodean; mientras que Uncle Tom se ofrecerá a sí mismo, con espíritu generoso y dócil, como la víctima inocente de un sistema brutal. Su muerte representa simbólicamente el triunfo cristiano sobre el infernal explotador, Simon Legree. Este proceso de «feminización» unido a la religión, que penetra toda la obra de Stowe, es para la historiadora Barbara Welter la clave de Uncle Tom's Cabin. La asignación de virtudes femeninas a la imagen de un Dios salvador en la figura de Uncle Tom la describe con estas palabras:

The female saviour is an interesting amalgam of nineteenth century adventism, the need for a Protestant counterpart to the cult of the Virgin, and the elevation of pure womanhood to an almost supernatural level ${ }^{19}$.

Por otro lado, conviene aclarar el hecho de que Stowe nunca se mostró partidaria de un feminismo radical, aun siendo su hermana más joven - Isabella Beecher Hooker- una de sus más fervientes defensoras. Y aunque sí estaba a favor del voto para la mujer, ella no fue miembro activo de dicho movimiento. Sin embargo, ideológicamente tanto Isabella como Harriet creian en el matriarcado como modelo de una sociedad justa y equilibrada, un modelo para la reconstrucción de América fundado en el precepto del amor como opuesto al poder patriarcal. Más aún, Stowe juzgará los valores femeninos como el fundamento de una revolución ética en América. De ahí que su último y más ardiente llamamiento como punto final de su obra vaya dirigido a las mujeres americanas, pues son ellas particularmente las «madres de la nación» sobre quienes recae la responsabilidad moral de perpetuar o bien echar por tierra la atroz institución de la esclavitud:

${ }^{18}$ Cfr. Harriet B. Stowe, Religious Studies (1877), in The Writings of Harriet Beecher Stowe, Boston, Houghton, Mifflin and Company, 1896, pp. XV, 36.

19 Barbara Welter, "The Feminization of American Religion, 1800-1860", in Dimity Convictions. The American Woman in the Nineteenth Century, Athens, Ohio University Press, 1976, p. 84. 
... And you, mothers of America, - you who have learned, by the cradles of your children, to love and feel for all mankind, -by the sacred love you bear your child... I beseech, pity the mother who has all your affectiones, and not one legal right to protect, guide, or educate, the child of her bosom!... I beseech you, pity those mothers that are constantly made childless by the American slave-trade! And say, mothers of America, is this a thing to be defended, sympathized with, passed over in silence? ${ }^{20}$

Lo que demanda de sus compatriotas es una respuesta individual; por eso, quienes "sienten» de un modo «firme, recto y bien fundado" una preocupación por los intereses de la humanidad, son los que verdaderamente hacen un gran bien al hombre. En definitiva, Stowe busca enfrentar a cada uno con su propia conciencia dejando que obre en consecuencia: «See, then, to your sympathies in this matter!» Su apelación a una reforma política o social se dirige al corazón del hombre y de la mujer, que quizá bajo la máscara de los dictados de la ley o de sus propios intereses, permite la crueldad de la esclavitud.

Desde luego, era evidente - al menos en las teorías puestas en boca de las primeras feministas- que el sufragio traería consigo la demolición de la doctrina de las dos esferas, al otorgar el voto a la mujer y reconocer su independencia e identidad desligada del marido. Pero en la práctica, el temor a dividir o enfrentar a ambos cónyuges - destruyendo así la paz familiar y social- frenó todo intento de emancipación. Es más, no supuso una violación del rol esencial de la mujer americana, sino que, por el contrario, significó una consumación de su maternidad, entendida como autoafirmación de la potestad femenina. En resumidas cuentas, la concepción tradicional de su naturaleza y carácter distintivo como madre y esposa quedaba completamente a salvo. El nuevo privilegio vino, pues, a ratificar su identidad como persona individual, junto al reconocimiento de su derecho a ser representada en la configuración política, social y económica del país.

Aun así, esto era sólo el comienzo de un largo proceso de emancipación, refrenado desde sus orígenes por su conexión con el movimiento abolicionista. Veamos cómo se desenvolvió gradualmente hacia la victoria. En efecto, desde 1832 se habian fundado varias sociedades antiesclavistas, tales como "The Antislavery Society of American Women" o "The Philadelphia Female Anti-Slavery Society", y se habian celebrado convenciones en las que por vez primera un grupo de mujeres dirigía una formidable campaña por la causa.

Dos agentes importantísimos de la cruzada abolicionista fueron las hermanas Grimké, anteriormente mencionadas. Sus arengas en torno a la abo-

${ }^{20}$ Harriet B. Stowe, Uncle Tom's Cabin, op. cit., pp. 623-4. 
lición atrajeron a muchedumbres de uno y otro sexo, de las que salian nuevos "conversos», dispuestos a apoyar dicho movimiento y fundar nuevas sociedades. Asi pues, frente a la denuncia y cólera de quienes protestaban al ver a estas mujeres hablar en público «en el sitio y con el tono que sólo correspondia al hombre como principal reformador», Sarah Grimké respondería con sus Letters on the Condition of Women and the Equality of the Sexes (1838). En ellas establecía un paralelismo entre la condición del esclavo y de la mujer, exigiendo para esta última una igualdad de derechos, de educación y de salario equiparados a los del hombre:

\footnotetext{
Men and women are created equal. They are both moral and accountable beings.
}

All I ask of our brethren is that they take their feet from off our necks and permit us to stand upright on the ground which God destined for us to occupy"1.

En definitiva, para quienes defendían los derechos humanos no había otra alternativa que la igualdad de ambos sexos. Pero la postura de las Grimké se salía del contexto fundamentalmente abolicionista; y los más conservadores acusaron dicha desviación de feminista, lo que dio lugar a una escisión dentro del movimiento. En un plano más intelectual y trascendentalista, Margaret Fuller también clamaría por la supresión de toda barrera arbitraria que obstaculizase el progreso de la mujer, porque lo verdaderamente necesario para ella era "as a nature to grow, as an intellect to discern, as a soul to live freely, and unimpeded to unfold such power as were given her ${ }^{22}$. Además, esta doble cruzada abolicionista y feminista encontraría el apoyo de una campaña organizada por «The State Women's Temperance Association» en contra del alcoholismo. Era necesaria una causa común para alcanzar el objetivo de la reforma y en concreto esta asociación demostraría de una manera efectiva el argumento de que la mujer siempre había sido y continuaba siendo «el agente moral», la fuerza promotora del bienestar social.

La abolición de la esclavitud, mediante "The Emancipation Proclamation» ( 1 de enero de 1863) por el presidente Abraham Lincoln, dejó el terreno libre para conquistar finalmente la victoria feminista. «The National

${ }^{21}$ Grimké, Sarah M.: Letters on the Equality of the Sexes and the Condition of Woman. op. cit., pp. 10 y 16.

22 Fuller, S. Margaret: Women in the Nineteenth Century, and Kindred Papers Relating to the Sphere, Condition and Duties, of Woman. Ed. by Arthur B. Fuller, with an introduction by Horace Greely. Boston, John P. Jewett \& Company, 1855, p. 38. 
American Woman Suffrage Association» -constituida en 1869-unificaría las dos ramas del movimiento originario, y una vez conquistada la libertad del negro, concentraría todas sus fuerzas en ganar el voto y la emancipación de la mujer. Sólo después de una lucha denodada y prolongada durante el último cuarto de siglo, "The Nineteenth Amendment» or "Anthony Amendment» fue aprobada en el Congreso el 26 de agosto de 1920, y la mujer americana vio colmadas sus esperanzas. Mas la conquista del sufragio no significó un absoluto respaldo a los postulados del movimiento feminista, pues el mundo de la política y los intereses del partido no constituían el principal aliciente o el fin específico de la mayoría de las mujeres. Sin embargo, la lucha que había llevado al triunfo representaba un logro mayor. Al participar democráticamente en las decisiones que habían de gobernar la vida de la nación, el voto femenino probaría su fuerza e influjo a lo largo de la historia como instrumento activo y eficaz en el cambio y progreso de la sociedad americana. Particularmente, este privilegio serviría de base a la nueva relación establecida entre las «dos esferas»: la nueva mujer del siglo $\mathrm{XX}$, educada, independiente y profesional venía a encarnar toda una serie de actitudes y aspiraciones - constantemente promocionadas por la literatura de la época y los medios de comunicación-encaminadas a reforzar el doble rol de compañera/esposa y profesional/autosuficiente que ostentaba en la sociedad moderna, eso sí, empeñándose por armonizar su matrimonio y su trabajo fuera del hogar. 